INDONESIAN JOURNAL OF ECONOMICS, SOCIAL, AND HUMANITIES

ijesh.unri.ac.id

\title{
Relevance and Challenges for Vocational Education Toward Demographic Dividend in Indonesia
}

\begin{tabular}{|c|c|}
\hline \multicolumn{2}{|r|}{$\begin{array}{l}\text { Muhammad Iqbal Jatmiko*, } \\
\text { Faculty of Social and Political Sciences, Gadjah Mada University } \\
\text { * mochamad.iqbal.j@mail.ugm.ac.id }\end{array}$} \\
\hline Article Info & Abstract \\
\hline $\begin{array}{ll}\text { Received } & : 2019-06-11 \\
\text { Accepted } & : 2019-07-15 \\
\text { Published } & : 2019-07-28 \\
\end{array}$ & $\begin{array}{l}\text { The writing of this paper is motivated by the transformation of } \\
\text { vocational-based education in the face of demographic dividend and } \\
\text { possible problems. This phenomenon is very important to be studied }\end{array}$ \\
\hline $\begin{array}{l}\text { Key words: vocational } \\
\text { education, demographic dividend, } \\
\text { unemployment }\end{array}$ & $\begin{array}{l}\text { vocational education in Indonesia. This article argues that there is a } \\
\text { productive relationship between increasing vocational education } \\
\text { through vocational secondary schools and diplomas with } \\
\text { demographic dividend transitions. This can be seen in the data } \\
\text { which show that there is a decline in the unemployment rate in } \\
\text { Indonesia, especially for vocational high school graduates; as an } \\
\text { impact of improving the quality and quantity of vocational } \\
\text { education. The writing of this article uses qualitative methods with } \\
\text { the support of secondary data from the Central Statistics Agency and } \\
\text { literature studies of various sources related to the issue of study. In } \\
\text { the results of the discussion, it was found a new discussion about the } \\
\text { role of the government in anticipating the increasingly rapid context } \\
\text { of the technological era so that there was no higher educated } \\
\text { unemployment. The distribution of inter-regional policies and } \\
\text { strengthening in technology qualifications are also potential sources } \\
\text { that must be developed again so that the demographic transition can } \\
\text { result in improvements in the country's economy. }\end{array}$ \\
\hline
\end{tabular}

\section{Introduction}

The discourse surrounding the phenomenon of demographic dividend in Indonesia has become a serious problem to be considered by various academics and the government. This happens because this phenomenon will become a window of opportunity as well as a very big problem if it is not implemented with the right procedure. The existence of a transformative situation that projects a rapid decline in the rate of birth, death, and the growth rate of a population of people makes its own problems to maintain its sustainability stably.

Regarding the context in Indonesia, the demographic dividend phenomenon is estimated to have occurred since 2012; as the starting point for a larger transition in the period 2028-2031 (Rimbawan, 2014, p. 39). In this period, the level of dependency ratio was at its lowest point, which was around $46.9 \%$. That is, in every number of 100 productive age residents will cover around 47 non-productive age residents. This condition will decline again in 2035 with the level of dependency ratio going up again to $47.3 \%$ due to the large composition of the elderly population.

In this case, the indicator of the growing number of productive ages of the population is increasing which seems to have its own resonance and profitability in the dimension of economic growth. Agree with Jati (in Maryati, 2015, p. 131) which states that economic benefits occur in line with the following requirements. First, the supply of large labor with quality that meets the 
needs of the labor market. Second, increasing income per capita as it gets productive employment opportunities. Third, increasing the role of women in the labor market for the number of children is getting less enabling women to enter the labor market and help increase family income. Fourth, there is an increase in community savings that are invested productively. Fifth, an increase in investment in human resources.

As a step in anticipating the demographic transition in Indonesia, it seems important to look at it from an educational perspective. This problem is because education today is very influential in creating human quality in the future, especially in fulfilling the qualifications of an increasingly educated workforce due to global competition. Indonesia's biggest challenge now focuses on improving human quality so that it can compete in global life (Zamroni, 2000, p. 33). Through an increasingly high level of education, it will encourage economic growth because people with high qualifications will be able to compete in the world of work. Agree with Surakhmad (2009) which explains that the lagging level of education can be a problem in decreasing the level of welfare of the nation as well as from poverty.

Therefore, it is important to see that education can be used as a medium to increase and optimize demographic dividend by increasing the competence of vocational education. This is because a higher-level workforce has better productivity and skills in the world of work (Crespo Cuaresma, Lutz, \& Sanderson, 2014). Thus, this article tries to explore and answer the problem formulation about the relevance and challenges of vocational education in relation to the demographic dividend provision in an effort to improve the economic welfare of the community. This problem is a crucial issue considering the potential of the productive age population is the main capital for the country to optimize the opportunity for a demographic dividend.

\section{$\operatorname{Method}(\mathbf{S})$}

This study uses a qualitative method with a descriptive analysis approach. The study was conducted by collecting secondary data from the Indonesian Central Bureau of Statistics and literature studies of various sources related to the issue of study. Secondary data are taken to cover the context of Indonesian society; the average for 2017. Later, the two data are compared to find and explain the conceptual findings.

\section{Findings and Discussion}

\section{Overview of Transitions and Demographic Dividend}

Discussing the phenomenon of demographic dividend in the context of Indonesia is actually an event that has a long historical background. If tracked further, the process began when the postindependence conditions in the 1950s were at a relatively high birth rate. Then in 1961-1971, there was a significant increase until the population growth rate reached $2.3 \%$ per year. Around the 1980s the government began to take the initiative to control population growth rates through Family Planning policies. Through the implementation of the policy, the government succeeded in reducing population growth to reach 1.4\% in 1980-1990 (Demographic \& Shifts, 2011, p. 8).

The success of demographic control and development programs since the New Order era up to now has led to the decade's demographic dividend phenomenon. This happens because the demographic transition process that has developed since a few years ago has been accelerated by a decrease in the Total Fertility Rate. As a result, the age structure of the population has changed which was once dominated by young people and then shifted to the productive age group. This condition is advantageous because the burden of dependency or economic support that must be provided by the productive age population to the non-productive population becomes lighter (Rimbawan, 2014, p. 39). 
The demographic transition process can principally be seen as a process of changing the composition of the age structure of the population caused by the movement of high birth and death rates towards low birth and death rates. According to Soemodinoto \& Suwandono (1997, p. 3) ) there are three main stages in the demographic transition. First, it is characterized by a decrease in birth rates and mortality; mortality rates are relatively faster than decreasing birth rates. Second, the decline in birth rates is faster than death. Third, it is indicated by a low mortality and birth rate with a low population growth rate.

\section{Figure 1. Demographic Transition Model}

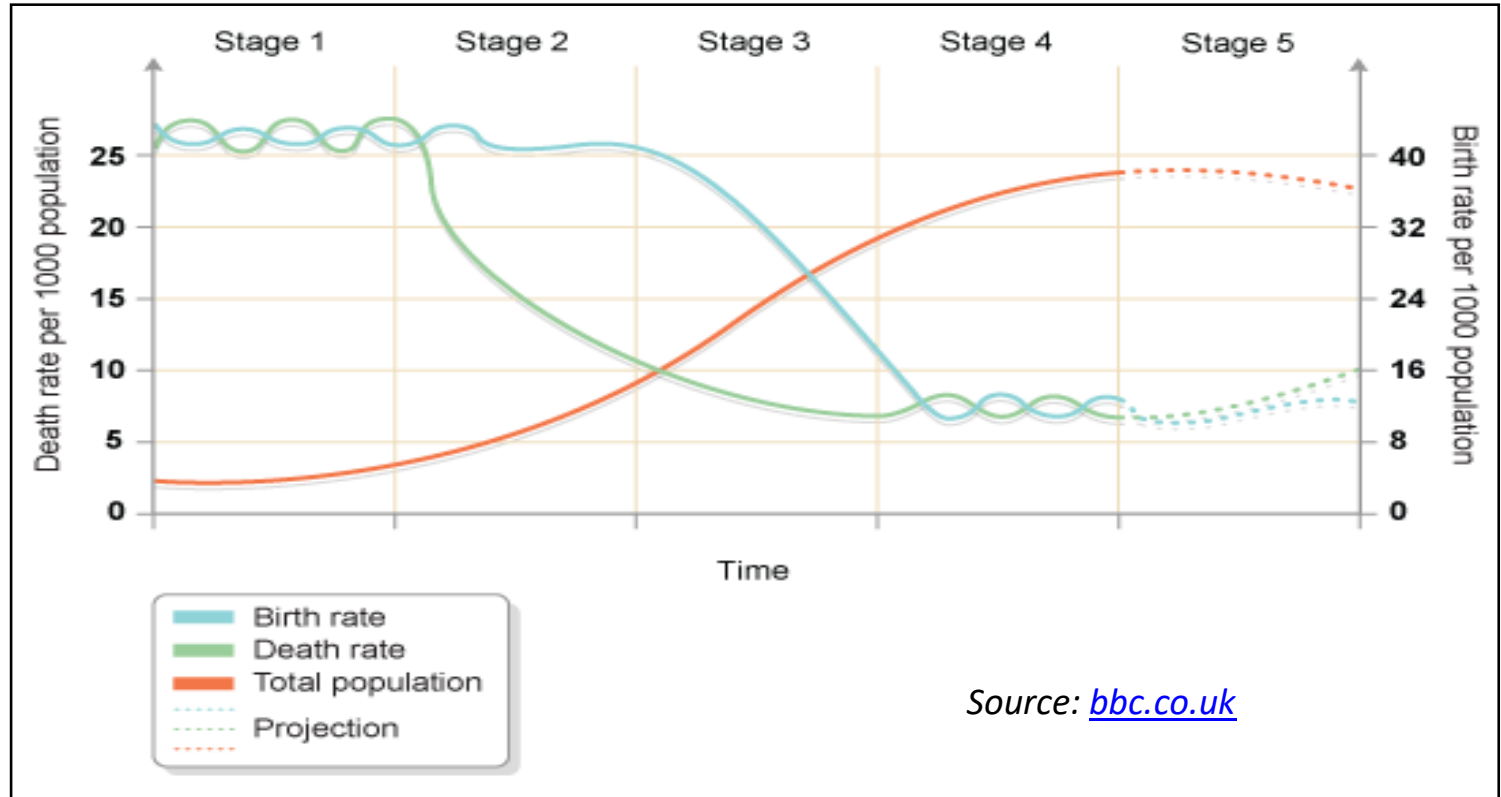

Other opinions for example - can be seen in figure 1- showing five stages in the demographic transition. First, it is indicated by the condition of a low population, but in a balanced condition; due to high birth rates and high mortality rates. Second, the population increases when the mortality rate decreases. Third, the population is still increasing rapidly, but the gap between birth and mortality has diminished. Fourth, the population is high, but it is balanced with a low birth rate and mortality rate. Fifth, the population at the highest level and will decline because the elderly population is increasing. Through the projections of demographic data, it is very supportive for academics, demographers, and the government to observe changes in population and prepare appropriate policies for social, economic and political issues of a country.

In Indonesia, the results of population projections based on Bappenas from 2010-2035 show that the population of Indonesia and the birth rate continue to decline to 4.29 million by 2035 , as seen in figure 2. However, the death rate will increase to reach 2.68 in 2035. Thus, it can be seen if the population dependency ratio will also decrease to $47.7 \%$ in 2035 from the original $50.5 \%$ in 2010 . 
Relevance and Challenges for Vocational Education Toward Demographic Dividend in Indonesia

Figure 2. Population Birth and Death Figures according to Bappenas 2010-2035

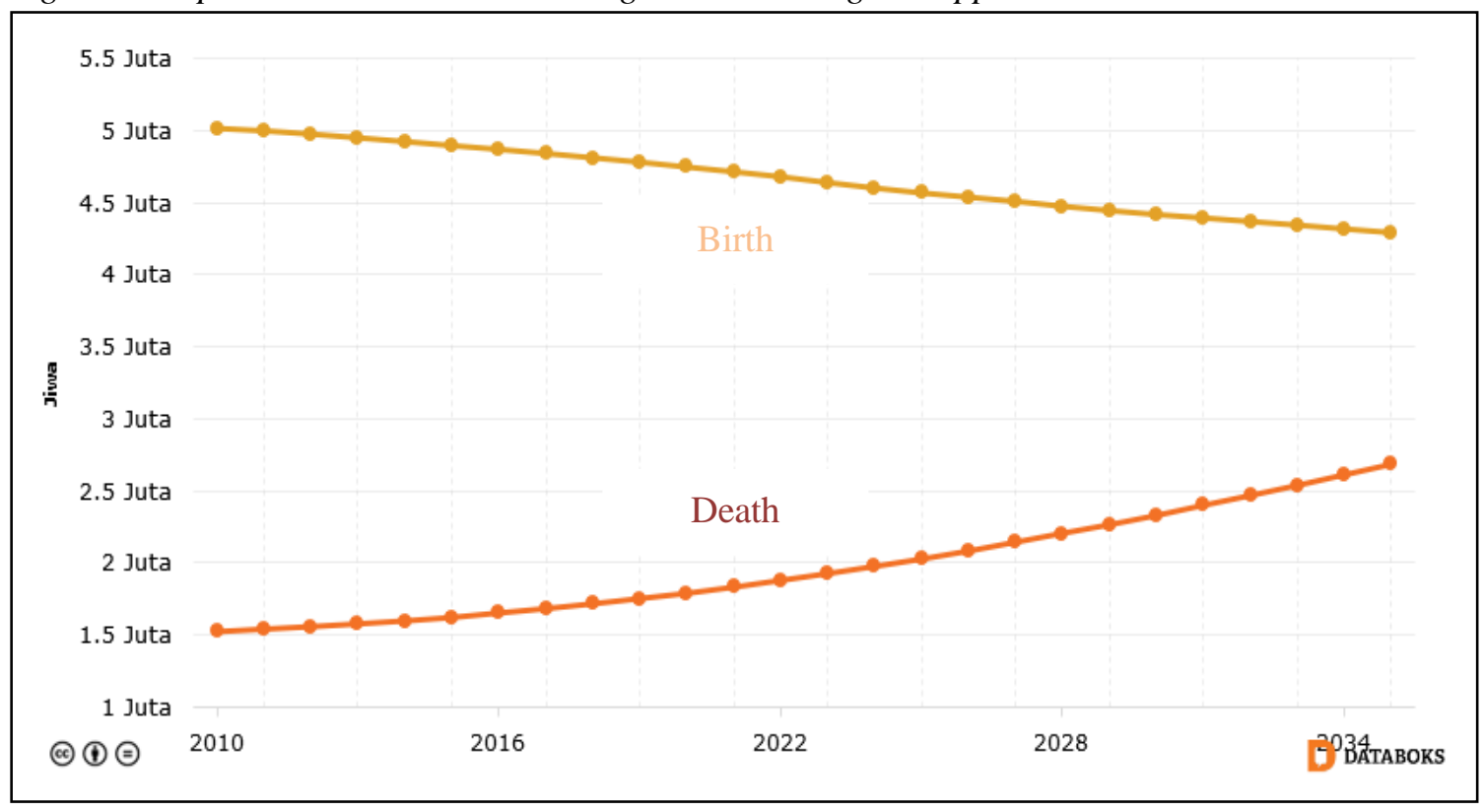

Source: katadata.co.id

This is already explained earlier that public health interventions through family planning programs are going well. In addition, the program can help couples reach the desired family size and can help reduce maternally or child mortality. Meanwhile, the mortality rate actually seems to increase as more and more transitions of the elderly population die, but with low and balanced intensity.

\section{Conditions of Vocational and Employment Education in Indonesia}

The utilization of the demographic dividend experienced by Indonesia should be done optimally, as a form of improving the quality of the economy and the welfare of the Indonesian people. Therefore, the relationship between population growth and economic development has become a very interesting topic in the realm of the country's political economy. Many of the countries take advantage of this opportunity by investing deposits in the form of infrastructure and the development of human resources appropriately, thus gaining a positive impact on the country's economic development. On the other hand, this aspect also poses challenges in terms of generating employment because labor supply is likely to exceed demand under labor market conditions (Navaneetham \& Dharmalingam, 2012, p. 283).

The need to analyze changes in age structure is important to use as the main indicator in measuring economic growth because each population group ages of the population have a different role in the economy. Questioning this, Indonesia has experienced the initial stages of demographic transition so that it has large productive human resources. The emergence of a demographic dividend can certainly be used as an opportunity for Indonesia to increase economic growth. One of them is through skills development based on vocational education. With the increasing number of workforce, reaching 128.1 million in 2017 and rising to 131 million in 2018, it is very possible for the government to obtain maximum results from the demographic dividend if handled correctly.

Today, the Indonesian government has begun to develop a system based on vocational education and vocational schools. The seriousness of the government in facing the demographic 
dividend benefits is evident in the increase in the number of polytechnic campuses. Based on data from the Ministry of Research, Technology and Higher Education in 2015, there were 3,227 universities, the total polytechnics in Indonesia reached 262 consisting of 43 state polytechnics, 53 official polytechnics, and 166 private polytechnics. This number began to increase compared to the previous year (Hamdani, 2019).

The concentration of the education curriculum is also arranged in the preparation of the prospects for labor in the market. In this case, vocational education will be emphasized in the manufacturing sector because its absorption reaches 575,000 people. In addition, other sectors that support more employment in agribusiness are as many as 195,843 people, tourism 3,333 people, health workers 6,018 people, migrant workers as many as 243,265 people, and digital economy 5,172 people (Widiartanto, 2018). The allocation given by the state is also not half-hearted, vocational education in 2019 received funding of Rp. 17.22 trillion, this amount is higher than in 2018 of Rp. 10.1 trillion. Later, the budget will be used to train 235 thousand workers, revitalize 12 Polytechnics, increase the competence of 6771 instructors, and procure training in 26 institutions. In addition, this budget is also intended for certification training, preparation of 1400 practice rooms at the Vocational Menennah School, as well as operational assistance for educational equipment (Dewi, 2019).

Along with the increase in applied education, it turns out that the number of working people has increased faster so that the national unemployment rate falls. According to the data in figure 3., it can be seen that the number of people working to grow faster than the workforce makes national unemployment decline. The number of people who did not work in 2015 reached 7.6 million, down to 7 million in 2018. Based on data from the Central Statistics Agency, the number of workers in August 2018 grew 2.47\% to 124.01 million from the previous August while the number of the workforce in the same period only grew $2.3 \%$ to 131.01 million from the previous period. As a result, the number of unemployed fell $0.57 \%$ to 7 million from before. In fact, in August 2017 the unemployment rate reached 7.04 million people with an Open Unemployment Rate of $5.5 \%$ of the total workforce. In other words, the national unemployment rate in August was $5.34 \%$, down from the previous year of $5.5 \%$ of the workforce; unemployment in urban areas is $6.45 \%$ and in rural areas it is $4.04 \%$.

Figure 3. Total Labor Force, Workers, and Unemployment in 2014-2018

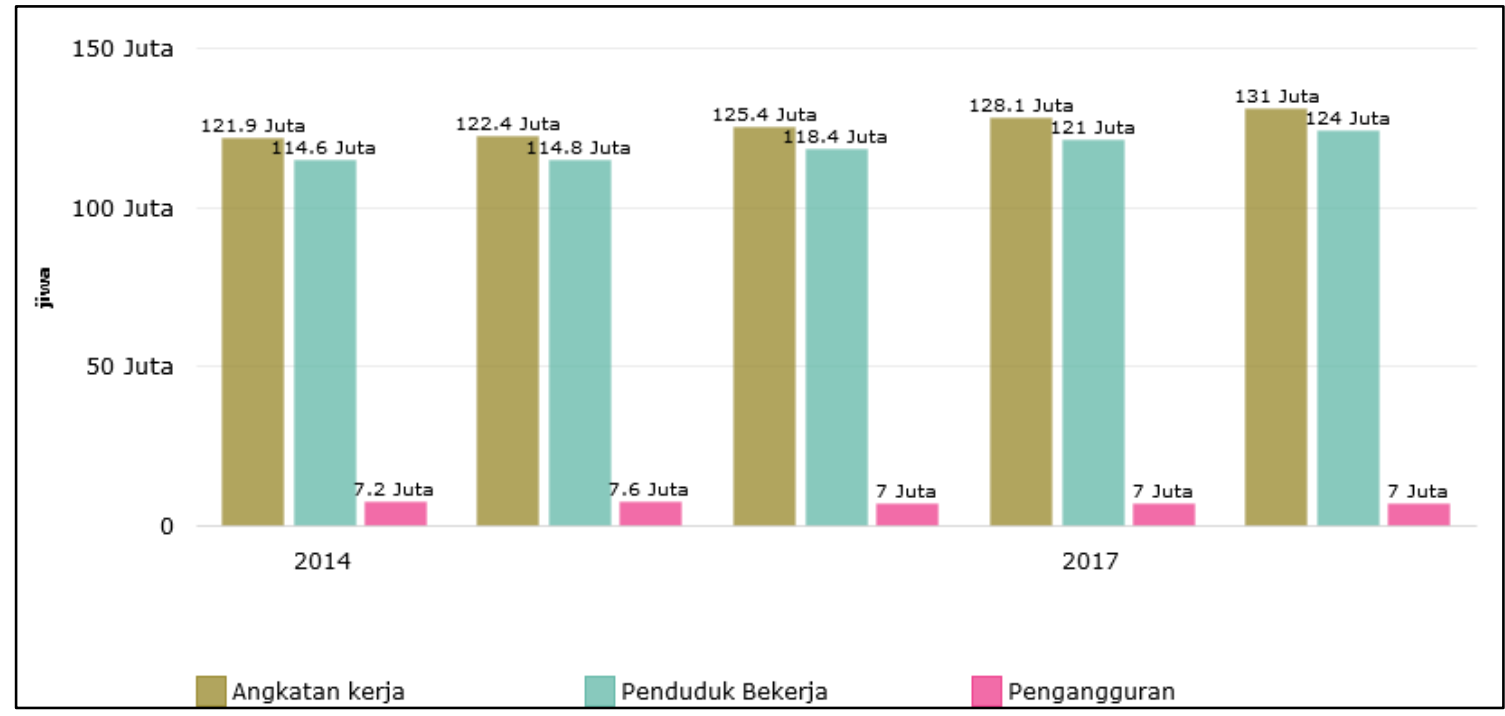

Source: katadata.co.id 
Relevance and Challenges for Vocational Education Toward Demographic Dividend in Indonesia

The implementation of Presidential Instruction Number 9 of 2016 concerning Revitalization of Vocational High Schools in the context of Improving the Quality and Competitiveness of Human Resources in Indonesia in fact went well. It is very important to reform the vocational education and training system by reorienting towards demand driven. Through the Ministry of Industry, students will be provided with facilities for field work and industrial apprenticeship programs. The program is structured with a model of coaching and the development of links and matches between Vocational High Schools and industrial partners. The planned mechanism aims to improve the quality of human resources to reach 1,775 Vocational High Schools covering 845,000 students who will be fostered and cooperated with 355 industrial companies in 2019. With this target, it is expected to produce 845 thousand certified graduates. For the 3-in-1 Training Program, the number of graduates is targeted at 162 thousand (Kementerian Perindustrian, 2018).

In 2019, Indonesia's employment conditions as of February showed significant results regarding the decline in unemployment of Vocational High Schools, from 9.3\% in February 2017 to $8.3 \%$ in February 2019. The decrease of $6.9 \%$ is the basis of the success and importance of applied education in Indonesia. However, the success was not followed by diploma education which also applied systems. The number of unemployed graduates who graduated from diplomas continued to increase, increasing by $8.5 \%$, previously at $6.4 \%$ in February 2017 to $6.9 \%$ in February 2019. Questioning this, the Indonesian government must strengthen and accelerate vocational-based education reform. The movement can be started by changing the focus of quantity towards quality, procurement which was originally government sponsored became a combination of government and non-government sponsored, and the general education system became a real vocational education system so that it was able to get maximum results (Sugandi, 2019).

The process of vocational education must also pay attention to other educational opportunities so that balance occurs. This happens because the pattern of universalization of applied and vocational-based education will increase unemployment and employment opportunities. For example, the number of unemployed with university graduates graduating rose $25 \%$ from $5.0 \%$ to $6.2 \%$. This seems to be influenced by a number of factors that are considered to cause an increase in educated unemployment. First, the lack of basic skills and abilities in meeting market demand opportunities; second, the provision of limited employment in Indonesia; third, income expectations and higher career status (Pusparisa, 2019).

The process of transforming education and the Indonesian government program is actually one of the implementations of optimizing the demographic dividend. More than that, the government must begin to see the current conditions of change in the context of society. There has been a change in the era of technological disruption which has caused automation throughout the work domain. If the government does not anticipate distortion change and still provides traditional vocational education - not referring to the acceleration of technology - it will be a big disaster for the survival of the Indonesian economy. In addition, the inequality of access to education in Indonesia which is very high - between urban areas and rural areas - becomes a serious locus that must be resolved in a balanced manner. Through the utilization of the potential of education, it will be a major factor driving economic growth (Lutz, Cuaresma, \& Sanderson, 2008) and has predictive power for future income development (Cuaresma \& Mishra, 2011).

\section{Conclusions}

The utilization of the demographic dividend experienced by Indonesia seems to need special revitalization in the formation of an optimal vocational workforce. Although the development and 
renewal of vocational curricula in Indonesia are still a bit constrained - financially and structurally - and requires a long process, this challenge must be carried out quickly and to the maximum extent possible. It is balanced by the expansion of employment distribution at the regional level which will reduce unemployment among educated graduates; diploma and university level.

Declining quality and career interest in work participation in the productive age in the formal sector is also a particular challenge. Many of the youth with higher education backgrounds try to work in the informal sector but are relatively unproductive. The assumption that the author sees is a consequence of education that does not provide and prepare the community to have skills in work. Thus, improving services in training and work preparation programs should be considered by the government in welcoming the demographic transition. Through a technological approach, the model will be a potential opportunity to improve the quality and productivity of prospective workers. On the other hand, the labor market program and labor exchange are one effective way to accommodate the level of educated unemployment, even though the solution has still not received serious attention in the scope of Indonesian society.

\section{References}

Crespo Cuaresma, J., Lutz, W., \& Sanderson, W. (2014). Is the Demographic Dividend an Education Dividend? Demography. https://doi.org/10.1007/s13524-013-0245-x

Cuaresma, J. C., \& Mishra, T. (2011). The role of age-structured education data for economic growth forecasts. Journal of Forecasting. https://doi.org/10.1002/for.1171

Demographic, F., \& Shifts, U. (2011). Indonesia's Intergovernmental Transfer, (November). Retrieved from http://documents.worldbank.org/curated/en/548511468260133592/pdf/684550ESW0P11900 Urbanization0shifts.pdf

Dewi, I. (2019). Revitalisasi Pendidikan Vokasi di Indonesia. Retrieved June 8, 2019, from https://www.kompasiana.com/irmadewi/5c827a2643322f7f05585b42/revitalisasi-pendidikanvokasi-di-indonesia

Hamdani. (2019). Pendidikan Vokasi Sebagai Model Pendidikan Masa Depan Indonesia oleh Hamdani Halaman all - Kompasiana.com. Retrieved June 8, 2019, from https://www.kompasiana.com/cangkoiburong/5ad4aa68caf7db6541258c72/pendidikanvokasi-sebagai-model-pendidikan-masa-depan-indonesia?page=all

Kementerian Perindustrian. (2018). Pemerintah Luncurkan Pendidikan Vokasi Industri di Jawa Timur. Retrieved June 8, 2019, from http://www.kemenperin.go.id/artikel/17197/PemerintahLuncurkan-Pendidikan-Vokasi-Industri-di-Jawa-Timur

Lutz, W., Cuaresma, J. C., \& Sanderson, W. (2008). The Demography of Educational Attainment and Economic Growth. Science, 319(5866), 1047-1048. https://doi.org/10.1126/science.1151753

Maryati, S. (2015). Dinamika Pengagguran Terdidik: Tantangan Menuju Bonus Demografi di Indonesia. Journal of Economic and Economic Education, 3(2), 124-136. Retrieved from https://media.neliti.com/media/publications/43023-ID-dinamika-pengangguran-terdidiktantangan-menuju-bonus-demografi-di-indonesia.pdf

Navaneetham, K., \& Dharmalingam, A. (2012). A Review of Age Structural Transition and Demographic Dividend in South Asia: Opportunities and Challenges. Journal of Population Ageing. https://doi.org/10.1007/s12062-012-9071-y 
Relevance and Challenges for Vocational Education Toward Demographic Dividend in Indonesia

Pusparisa, Y. (2019). Angka Pengangguran Lulusan Universitas Meningkat. Retrieved June 8, 2019, from https://katadata.co.id/infografik/2019/05/17/angka-pengangguran-lulusanperguruan-tinggi-meningkat

Rimbawan, N. D. (2014). Bali Diproyeksikan Mengalami Bonus Demografi Puncak 2020-2030: Peluang atau Bencana. Piramida, 10(1), 37 - 44.

Soemodinoto, S., \& Suwandono, A. (1997). Kecenderungan Transisi Demografi dan Epidemologi Suatu Fenomena Penting Terhadap Masalah Gizi dan Kesehatan pada Pra-lansia dan lansia. Buletin Penelitian Sistem Kesehatan, 1(1), 1-22.

Sugandi, B. (2019). Menggagas Reformasi Sekolah Vokasi di Indonesia. Retrieved June 8, 2019, from https://edukasi.kompas.com/read/2019/03/30/13410431/menggagas-reformasi-sekolahvokasi-di-indonesia?page $=$ all

Surakhmad, W. (2009). Pendidikan Nasional Strategi dan Tragedi. Jakarta: Kompas Press.

Widiartanto, Y. H. (2018). Pemerintah Fokuskan Pendidikan Vokasi ke 6 Sektor Industri. Retrieved June 8, 2019, from https://ekonomi.kompas.com/read/2018/04/20/222900726/pemerintah-fokuskan-pendidikanvokasi-ke-6-sektor-industri

Zamroni. (2000). Paradigma Pendidikan Masa Depan. Yogyakarta: Bigraf Publishing.

Sumihar, S. S. (2014). Meningkatkan Kinerja Guru Biologi SMA Negeri dalam Pembelajaran melalui Supervisi Klinis. Jurnal Manajemen Pendidikan Indonesia, 6(2).

Susanto, H. (2012). Faktor-faktor yang Mempengaruhi Kinerja Guru SMK Negeri 1 Daha Selatan Kab. Hulu Sungai Selatan Kal-Sel. Jurnal Pendidikan Vokasi, 2(2).

Suwardi. (2009). Hubungan Guru terhadap Supervisi Klinis dan Bantuan Supervisor dengan Kinerja Guru SMA Negeri di Kabupaten Magelang. Surakarta: Tesis Pascasarjana Universitas Sebelas Maret.

Yogaswara, A. (2010). Kontribusi Manajerial Kepala Sekolah dan Sistem Informasi Kepegawaian terhadap Kinerja Mengajar Guru. Jurnal Penelitian Pendidikan, 1 (2). 